away from it; and it is no doubt difficult to understand how, if some molecules are constantly being carried away from the brain and others added to it, the neurorheuma stored up should ramain. But may not the process be something of this fashion: as fast as a destructive chemical change goes on in any molecules in which neurorheuma is stored up, it is set free, but is immediately taken up again by the molecules resulting from the constructive chemical change that is continually going on. Possibly the exactitude with which this process takes place determines whether or not memory shall be good, for it undoubtedly might determine whether or not the neurorheuma should remain; so that, in pathological language, we should say that a person with a bad memory was one in whom the neurorheuma was not accurately transferred from the old molecules which were broken down to the new ones which were built up, whilst a person with a good memory was one in whom they were accurately transferred. Broadly speaking, it may be said, that a nerre is alive so long as it is capable of transmitting neurorheuma, and dead when it cannot do so; and probably we should be as near as possible to a correct definition of the distinction between life and death if we said that in the former the cardiac and respiratory nervous systems were capable of transmitting neurorheuma, and in the latter they were not.

My object has not been, however, to discuss these abstruse problems, but merely to suggest that the term "neurorheuma" is an advantageous one, as I hope I have shown by the use of it, and also to throw out the hypothesis that there may be not one but many neurorheumas.

St. Thomas's-street, E.C.

PERORATION TO MY REMINISCENCES OF FIFTY YEARS' STRUGGLE, IN THE FOOTSTEPS OF WILLTAM HARVEY, TO SEARCH OUT CRUCIAL FACTS IN PHYSIOLOGY.

BY T. WHARTON JONES, F.R.C.S., F.R.S.

A NoT uncommon incident in the history of institutions, how good and just soever their object may be, has been the formation of cliques who, having for the time got power into their hands, look to the serving of their own purposes rather than the honest fulfilment of the avowed obj the institutions themselves. John Wicliffe denounced the Church Courts of his time as dens of thieves and larders of hell, and their officers as subtle in malice and covetousness. In Ireland, where the ecclesiastical jurisdiction in Roman Catholic times had been even more corrupt and oppressive than in England or elsewhere, Bıshop Budell, of Kilmore, found, to his sorrow, the Ecclesiastical Courts still unreformed under the Protestant régime. Consecrated in September, 1629 , he had not long entered on his sacred functions before complaints reached him of oppression and extortion suffered by the poor people in the Ecclesiastical Courts. This was the more grievous, seeing that the cause of complaint was given by the Bishop's own officers, and the wrongs committed in his own name.

In a letter to Archbishop Laud, at the time Bishop of London, Bishop Bedell complains of this oppression exercised by the Court Ecclesiastical, which, said he, "in very truth, my lord, I cannot excuse, and do seek to reform." His attempts at reform, however, stirred up against him the most virulent rage and malice on the part of the officers of Church Courts throughout the country, as well as of the chancellor of his own dioceses of Kilmore and Ardagh in particular. His right reverend brethren, the bishops, whose cause it was equally with his own, though they at first applied to him by way of compliment the saying of the Emperor Theodosius in respect to Ambrose, Archbishop of Milan, "Solus Kilmorensis novit se gerere ut episcopum," gave him no further countenance. This much mortified Bishop Bedell, for had his brethren joined in supporting the cause which so nearly concerned themselves and the well-being of the Church in Ireland, some better result might have accrued. Even Archbishop Ussher, whose Court was reputed to be as corrupt as others, if not worse, though he himself was so good a man, yielding to the influence of his chancellor, stood aloof. Turning again, therefore, to Archbishop Laud, Bishop Bedell wrote, saylng: "For my part, God is my witness that if I thought I could be excused in conscience for the misgovernment of the people whom God and his Majesty have committed unto me, I could easily submit to be superseded in the exercise of the jurisdiction, though there be left me nothing but the name of it; when, however, the blame also and the shame of religion lie upon it, I hope good men will not account me pragmatical if $I$ be sensible, and desire to fulfil the profession made at my consecration, that $I$ would be gentle and merciful, for Christ's sake, to poor and needy people and such as be destitute of help. These poor people do beseech your lordship, and, by you, his Majesty, to pity them. Religion entreats you to remove this scandal -the Church to reform this disorder. I have said and done what I can; I leave the success to God."

Laud's reply to this appeal was sufficiently frank, friendly, and well-considered; but he thought that not much could be done, seeing that all the practitioners of the civil law were combined to resist any reform, whilst the bishops themselves tamely succumbed to the tyranny of their own officers. Under such circumatances, therefore, the said officers, "sotil in malice and covetisse" as they were, prevailed against the generous purpnse of the heroic bishop, who was, among the faithless, faithful only found.

Wicliffe knew by experience the persecution which a translator of the Holy Scriptures into the vernacular brought down upon himself, but he could never have believed that in a Reformed Church opposition would have been offered to the translation of the Old Testament into Irish such as that which Bishop Bedell encountered. Indeed, the singular character of the opposition by churchmen; the subsequent narrow escape of the MS. from the hands of the Irish Roman Catholic rebels by the intervention of the Rer. Denis Sheridan, a Protestant minister, head of the Sheridan clan, and ancestral kinsman of Richard Brinsley Sheridan; its preservation for forty or fifty years by Bishop Jones, of Meath, previously Dean of Kilmore; its revision, as a labour of love, by an Irish convert to Protestantism, who had been a Jesuit professor in Spain, and Superior of the Jesuit Mission in Ireland; the eventual publication of the work under the auspices of the Hon. Robert, Boyle; and its use, not only in Ireland, but also among the Gaelic-speaking people of the Scottish Highlands for nearly the whole of the eighteenth century, - form a curious history.

Bishop Bedell employed as chief translator a Mr. Murtagh King, who had been recommended to him as an able Irish scholar, and from whom he had himself taken lessons in the language while Provost of Trinity College. The bishop, thus satisfied of the competency of Mr. King t i preach the Gospel to an Irish-speaking parish, admitted him to holy orders and collated him to a benefice. The poor man, however, was not only slandered, but positively robbed of his benefice on false pretences, and persecuted, notwithstanding all the protection the bishop could afford him. In a letter to Lord Deputy Wentworth, afterwards Earl of Strafford, urging a restitution to Mr. King of the benefice of which he had been so unjustly deprived, Bishop Bedell thus expressed himself: "The Bishops of Rome themselves, after most formal proceedings, do grant.' restitutionem in integrum,' and acknowledge that 'sententia Romæ sedis potest in melius commutari""; adding: "My lord, if I understand what is right, divine or human, these be wrongs upon wrongs, which, if they reached only to ${ }^{\circ} \mathrm{Mr}$. King's person were of less consideration; but when through his side that great work, the translation of God's Book, so necessary for both his Majesty's kingdoms, is mortally wounder, pardon me, I beseech your lordship, if I he sensible of it."

In 1610 Bishop Adair of Kilala was, at the instance of the Earl of Straff. rrd, brought before the High Commission Court on the frivolous charge of having spoken apologetically of his countrymen, the Scottish Covenanters, and sentenced to deprivation. At the trial, Bishop Bedell of Kilmore, as a member of the Court, in delivering his jindgment. stood out for the most favourable construction of Bishop Adair's conduct, arguing that it involved no spiritual offence nor any error in life or doctrine such as may make a bishop deserving of censure. All the other memhers of the Court, however, gave their verdict against the Bishop of Kilala. According to what was alleged to have been the secret history of this transaction, the deprivation of Bishop Adair was a thing determined on for the purpose of creating a vacancy in the Jrish episcopate for a Scottish bishop who had come to Ireland, a refuge from the anti-prelatic wrath of the Covenanters of Scotland. 
In bravely standing up by himself in defence of a man unjustly prosecuted, Bishop Bedell was checked and chidden for his pains by the higher powers at the time, as a wilful and sinvular person to differ from the unanimous decision of so honourable a Court! Nevertheless, restitution by anuulment of the sentence of deprivation passed against Bisnop Adair and his appointment to another bishopric was subsequently made by command of King Charles 1., when, after the death of Strafford, his Majesty came to be informed of the circumstances of the case.

Whother any repuration was ever made to Mr. Murtagh Kin does not appear, though it is most likely that he "dropped into the grave unpitied and unknown." A "memorial" of him, however, and that not a "frail" one, still exists in the Irish translation of the Old Testament. The man who was active in despoiling Mr. King of his benefice with the assistance of the corrupt Ecrlesiastical Court, in order to get it for himself, was a refugee Scottish episcopalian minister, as was also the accuser of Bishop Adair of Kilala. The fate of these two worthies, however, was different-the former, notwithstanding the incredible injustice of his proceedings, being eventually made a bishop, wheruas the latter was beaten to death by a band of Irish rebels.

l'tle instances now related, as well as many others which could be quoted, exemplify how my ancestral cousin, Bishop $B$-dell of Kilmore, was opposed by falsehood, slander, fraud, forgery, and theft in his endeavours to fulfil the duties of his sacred office. The instances narrated in preceding numbers of THE LANCET, from among my reminiscences of a fifty years' struggle to follow in the footsteps of William Harvey in promoting physiological knowledge in its relatinns to merical science, may be compared, in a small way, mutatis mutandis, to the experiences of Bishop Bedell. The said instunces also, I venture to think, warrant me in addrussing, as I now do, the General Medical Council, Universities, Colleges of Physicians, Colleges of Surgeons, and all other authorities-whether individuals or bodies corporate-whom it may concern, to protest against the incongruous teachings by which the minds of students of medicine are distracted, and to urge a plea for their bettier instruction in a knowledge of fundamental facts-such, for example, as the observable mechanism and action of the vessels in the extreme circulation of the blood, resarding which their professors, under the auspices of the autrorities $I$ am ardressing, seem to be ignorant either from incapacity or wilfulness.

T, conclude, let those who think they know, without ever having lo ked to see, review their supposed knowledge and ext, their thoughts over again ; and if, in the particulars, they find they have mistaken words and fancies for realities, and accepter the dicta of pretenders instead of the evidence of observed facts, let them correct the record and acknowledge the truth as it is in nature. Moreover, let them remenber that he who propagates a delusion, and he who connives at one when already existing, both alike tamper with the truth, and that we must neither lead nor leave men to mintake falsehood for truth. Not to undeceive is to deceive.

Ventnor, Isle of Wight.

\section{ON THE TREATMENT OF ORCHITIS AND EPIDIDYMITIS.}

BY FREDERICK W. LOWNDES, M.R.C.S, SURGEOY TO THE LIVERPOOL LOCK HOSPITAL.

There is a sufficient diversity of opinion as to the best tre 2 t, nent of orchitis and epididymitis, the result of acute gon orchoe $i$, to induce me to give our experiences at the Li recesul Losk Hospital. When I first became surgeon, eleven years ag), [ found that the practice adopted in all thise cises was that which had been suggested by Mr. Furntula Jordan in 1939-viz., by painting the affected teitcie with a strong sulution of nitrate of silver (two drachms to one ounct), at the same time enforcing strict $r \rightarrow s^{r}$ in bed and supporting the inflamed organ upon a small pillow, so as to provent it fro'n hanging down. It had been a loptal for so:De years previously by Messrs. Worthington an 1 If $c$ reane, who were the surgeons to the hospital at the tiune when Jrr. Jurilan sagrester this mode of treatment; and also by Mr. Chuunsy Puzey, who susceeded

Mr. Worthington, during the two years of his surgeoncy. I have invariably pursued the same treatment now for eleven years, and so has my colleague, Dr. Armand Bernard, who succeeded Mr. McCheane in 1882, and has thus had four years' experience of the treatment.

At my request the resident superintendent of the hospital, Mr. Serjeant, has given me the following statistics of all the cases of orchitis and epididymitis combined from June 1st, 1875 , to June 1st, 1886, an interval of eleven years. The numbers are as follows:-

Years.

1875 to 1876

1876 to 1877

1877 to 1878

1878 to 1879

1879 to 1880

1880 to 1881

1831 to 1882

1882 to 1883

1883 to 1884

1884 to 1885

1885 to 1886

$$
\begin{aligned}
& \begin{array}{llllllll}
\ldots & \ldots & \ldots & \ldots & \ldots & \ldots & \ldots & 32
\end{array} \\
& \begin{array}{lllllllll}
\ldots & \ldots & \ldots & \ldots & \ldots & \ldots & \ldots & 15
\end{array} \\
& \begin{array}{llllllll}
\ldots & \ldots & \ldots & \ldots & \ldots & \ldots & \ldots & 22
\end{array} \\
& \begin{array}{llllllll}
\cdots & \cdots & \cdots & \cdots & \cdots & \cdots & \cdots & 28
\end{array} \\
& \begin{array}{llllllll}
\cdots & \ldots & \ldots & \ldots & \ldots & \ldots & \ldots & 30
\end{array} \\
& \begin{array}{llllllll}
\ldots & \ldots & \ldots & \ldots & \ldots & \ldots & \ldots & 16 \\
& \ldots & \ldots & \ldots & \ldots & \ldots & \ldots & 31
\end{array} \\
& \begin{array}{llllllll}
\ldots & \ldots & \ldots & \ldots & \ldots & \ldots & \ldots & 28
\end{array} \\
& \begin{array}{llllllll}
\ldots & \ldots & \ldots & \ldots & \ldots & \ldots & \ldots & 28 \\
\ldots & \ldots & \ldots & \ldots & \ldots & \ldots & \ldots & 24
\end{array} \\
& \begin{array}{llllllll}
\ldots & \ldots & \ldots & \ldots & \ldots & \ldots & \ldots & 18
\end{array} \\
& \begin{array}{lllllll}
\ldots & \ldots & \ldots & \ldots & \ldots & \ldots & 25
\end{array} \\
& \begin{array}{llllll}
\text { Total } & \ldots & \ldots & \ldots & \ldots & \overline{269}
\end{array}
\end{aligned}
$$

All these were patients admitted into the hospital; we have no out-patients.

I have always found the treatment I have mentioned most successful. The acute pain, often amounting to agony, is soon subdued, and in the majority of cases the testicle returns to its normal size in the course of a few days. Sometimes a second painting is necessary, but this suffices. In private practice $I$ have al ways used the same application. When patients can be induced to take absolute rest in bed, the result is equally successful as in the hospital. When, however, patients are compelled to follow their usual occupations, the recovery must obviously be slower, as it is impossible by any suspensory bandages or by handkerchiefs, however skilfully applied, to ensure such perfect rest for the testicle as when the patient is lying in bed. I have heard it argued that rest in bed is sufficient of itself to effect a cure, but a very few cases so treated with spirit lotion as an application has convinced me that it is not so. The immediate effects of the nitrate in allaying the pain are most marked, though for obvious reasons the nitrate must act more powerfully upon the testicle while in a state of quiescence than when constantly moved, however slightly.

Mr. Jordan has informed me that he still pursues the same treatment, having every reason to be satisfied with it. It seems to me to be only just to him to give this very satisfactory proof of the value of the treatment which he originally suggested.

Liverpool.

\section{CASES OF ORBITAL N 2 EVI TREATED BY ELECTROLYSIS. ${ }^{1}$}

By SIMEON SNELL, L.R.C.P. LOND., M.R.C.S., OPHTHALMIC SURGEOY TO THE SHEFFIELD GENERAL INFIRMARY AND TO THE INSTITUTION FOR THE BLIYD.

THE following instances are good examples of the value of electrolysis in the treatment of nævus. One of them was more confined to the eyelid, but the others extended deeply into the orbit. It would not, 1 believe, have been easy to treat them with a ligature; and without discussing different methods of treatment, it may be doubted whether any other plan would have resulted in such an absence from deformity as was the case in these instances. A drawback, of course, to the use of electrolysis is that it may be neces. sary to repeat it several times. A feature in these cases is the similar situation in each.

CASE 1.-Rosina B- aged three months, came first under my notice at the Sheffield General Infirmary in November, 1831. A nævus, apparently cutaneous, was situated in the upper eyelid, towards the inner angle, at its upper part. This was cauterised with the actual cautery, and the child disappeared. In June, 1882, she again came to me. The navus had greatly increased in siz:; it was nearly as large

1 Read before the Sheffid Medico-Chirargical Society. D 2 